\title{
Analysis of the information for positioning of companies with operations in Sofia and the 24 districts of the capital municipality
}

\author{
Maria Popova-Hristova ${ }^{1 *}$ \\ ${ }^{1}$ Sofia Investment Agency, Sofia, Bulgaria
}

\begin{abstract}
This study is the first step of an initiative of the Invest Sofia for Mapping the Industry in Sofia. As an agency whose main function is to attract investments in the city, we need information about where in the city what industry is developing, what are the prerequisites for the development of the ecosystem, how many are employed in the sector, what revenues are realized in a certain area. These are data that we could provide to potential investors and assist them in choosing the most suitable for their business location and for realizing their investment intention in the city. Thanks to the data from the survey, we will be able to put in strategic documents for the city necessary follow-up in order to further develop the region in one direction.
\end{abstract}

\section{Introduction}

This publication is part of a study 'Map of Industries: Head Offices in Sofia by Regions' which includes an analysis of 116 companies operating in Sofia and their offices in the 24 districts of Sofia Municipality. In the survey, the companies are distributed by type of industry and by the size of the annual turnover of the enterprise and allows potential investors to follow the city's development by regions.

In the study 'Map of Industries: Head Offices in Sofia by Regions' are included companies with annual revenue of up to EUR 50 million (93 companies), up to EUR 100 million, up to EUR 250 million, and with over EUR 250 million annual turnovers. The data are from 2019 [1].

\section{Materials and methods}

The purpose of the study is to establish the sectors of activity, as well as the appointed employees of companies with annual revenue over BGN 20 million, which will orient the potential investors for the development trends in the different regions of Sofia allows potential investors to follow the city's development by regions.

*Corresponding author: maria.hristova@investsofia.com 


\section{Results and discussion}

Number by Sofia Municipality, Region ( $n=116)$

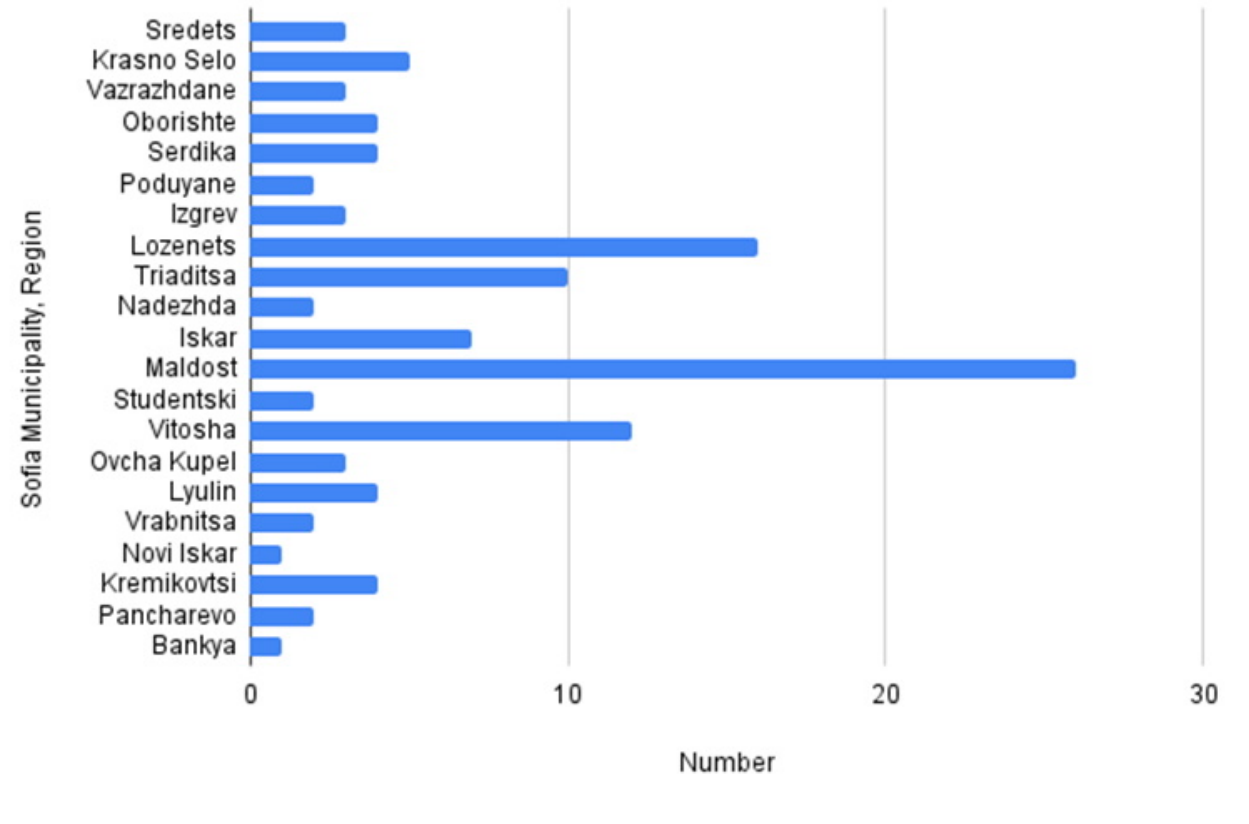

Fig. 1. Most campaigns that fall within the criteria we are considering are in the regions: Mladost 26, Lozenets - 16, Vitosha - 10, and Triaditsa - 12 .

\section{Revenue by Sofia Municipality, Region ( $n=116)$}

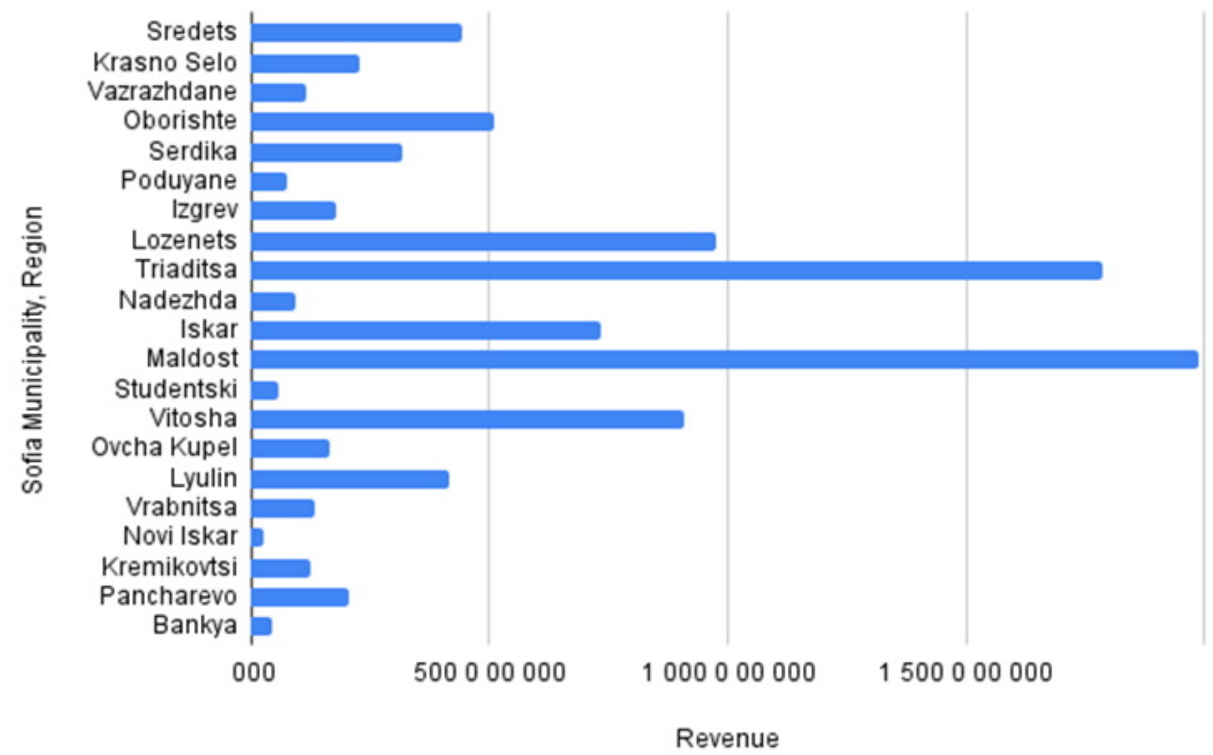


Fig. 2. Revenue record holders are Mladost - 1988759 000, Triaditsa - 1787449 000, Lozenets 977246000 , Vitosha - 908921000 .

\section{Employees count by regions Sofia Municipality}

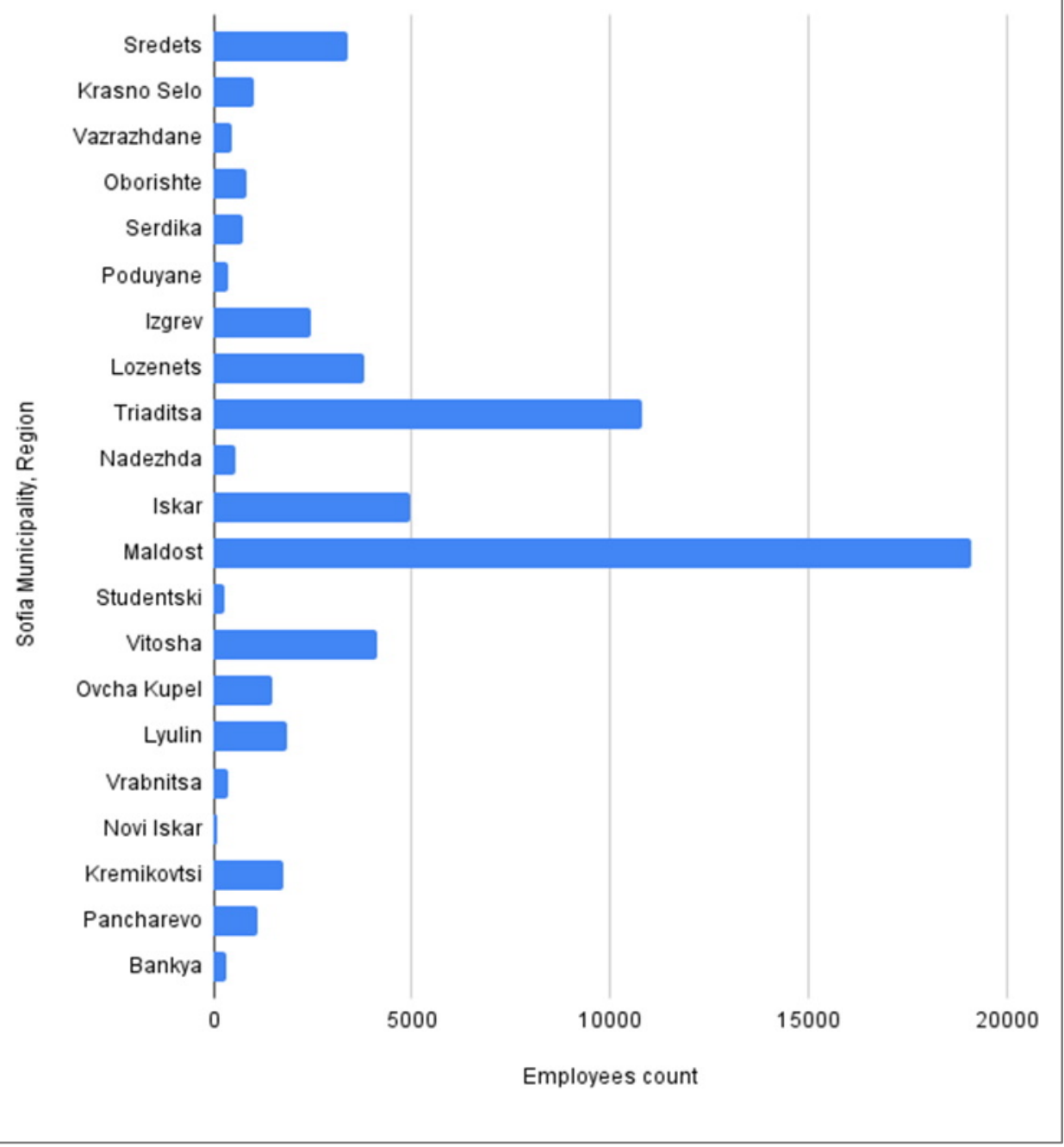

Fig. 3. Nearly 20000 people work in Mladost, just over 10000 in Triaditsa, and just under 5000 in Vitosha and Lozenets. 


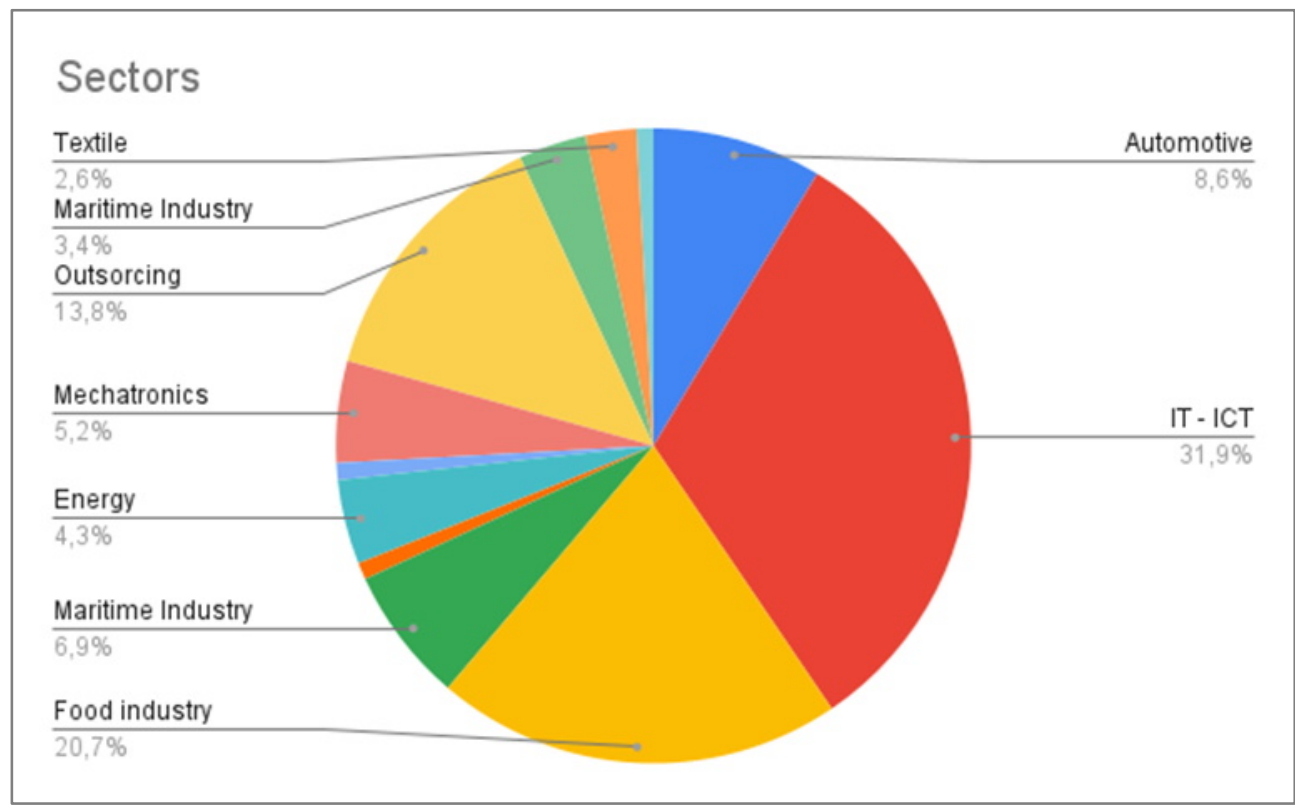

Fig. 4. 31,9\% IT - ICT Sector , 20,7\% Food industry, 13,8\% Outsourcing

\section{Leaders and Very large - annual revenue over and under 250 million euro}

In this publication, we analyze one company by category 'Leaders - annual revenue over 250 million euro' and 12 companies in the category 'Very Large - annual revenue under 250 million euro'.

Table 1. 'Map of Industries: Head Offices in Sofia by Regions'.

\begin{tabular}{|c|c|c|c|}
\hline companies & Companies & Sector \\
\hline $\begin{array}{c}\text { Sofia Municipality, } \\
\text { Triaditsa Region }\end{array}$ & 3 companies & $\begin{array}{c}\text { Cargill Bulgaria } \\
\text { ABB Bulgaria EOOD } \\
\text { ADM Bulgaria Trading } \\
\text { EOOD }\end{array}$ & Autsourcing \\
\hline $\begin{array}{c}\text { Sofia Municipality, } \\
\text { Maldost Region }\end{array}$ & 2 companies & $\begin{array}{c}\text { Bultive Industry } \\
\text { Buria EOOD } \\
\text { Schneider Electric } \\
\text { Bulgaria EOOD }\end{array}$ & IT - ICT \\
\hline $\begin{array}{c}\text { Sofia Municipality, } \\
\text { Sredets }\end{array}$ & 1 company & $\begin{array}{c}\text { Montupet EOOD } \\
\text { Automotive }\end{array}$ & Automotive \\
\hline $\begin{array}{c}\text { Sofia Municipality, } \\
\text { Oborishte Region }\end{array}$ & 1 company & Bulgarian Energy & Holding EAD \\
\hline $\begin{array}{c}\text { Sofia Municipality, } \\
\text { Serdika Region }\end{array}$ & 1 company & ETEM Bulgaria S.A. & Automotive \\
\hline
\end{tabular}




\begin{tabular}{|c|c|c|c|}
\hline $\begin{array}{c}\text { Sofia Municipality, } \\
\text { Lozenets Region }\end{array}$ & 1 company & Monbat AD & $\begin{array}{c}\text { Mechatronics / } \\
\text { Automotive }\end{array}$ \\
\hline $\begin{array}{c}\text { Sofia Municipality, Iskar } \\
\text { Region }\end{array}$ & 1 company & $\begin{array}{c}\text { Sensata Technologies } \\
\text { Bulgaria EOOD }\end{array}$ & Automotive \\
\hline $\begin{array}{c}\text { Sofia Municipality, } \\
\text { Vitosha Region }\end{array}$ & 1 company & $\begin{array}{c}\text { Coca - Cola Hellenic } \\
\text { Bottling Company } \\
\text { Bulgaria }\end{array}$ & $\begin{array}{c}\text { Outsourcing / Food } \\
\text { industry }\end{array}$ \\
\hline $\begin{array}{c}\text { Sofia Municipality, } \\
\text { Lyulin Region }\end{array}$ & 1 company & Nestle Bulgaria AD & Food industry \\
\hline
\end{tabular}

From the results obtained we get an idea of the distribution of the annual revenues of the business in Sofia. The leading sectors by region are emerging concretely and clearly. The creation of a digital map of the industry in the city will give us an idea of the distribution by type of business activity, revenue, workforce, as well as trends for the development of the regions. Such a function and task are assigned to Sofia investment agency. The role of the Agency on the one hand is to attract potential investors and, on the other hand, to existing and operating ones in the territory of the city. The provision of data, statistics, and detailed information on the gross domestic product, human resources, and other economic indicators is part of the daily life of the Agency's team. Once collected in one place in a digital format and properly maintained systematically, this information will contribute to the optimization of human resources, time, and money.

Interesting and useful information that would influence an investor to realize their investor intention in the city is the future investments that the current companies plan to make. This data should also be added to the industry map after the business survey to provide an insight into the ecosystem and the upcoming changes in the city. Being a municipal structure, the Agency has municipal investment intentions.

\section{Conclusion}

The sectors that have realized the most revenues in the regions of Sofia are IT - ICT; Food industry and Outsourcing.

The regions with leading indicators in terms of realized revenues attracted companies with annual revenue for 2019 over BGN 20 million and number of employees are Mladost, Triaditsa, Lozenets, Vitosha, and Iskar.

\section{References}

1. 'Map of Industries: Head Offices in Sofia by Regions', Sofia Invest (2020), https://investsofia.com/en/download-new-report-map-industries-head-offices-sofiaregions/, [Accessed: June 2021]

2. https://montupet.bg/, [Accessed: November 2020]

3. https://bgenh.com/en, [Accessed: November 2020]

4. https://www.etem.bg/en, [Accessed: November 2020]

5. http://www.monbat.com/, [Accessed: November 2020]

6. http://www.cargill.bg/, [Accessed: November 2020]

7. https://global.abb/group/en, [Accessed: November 2020]

8. https://www.adm.com/adm-worldwide/europe/bulgaria-bg, [Accessed: November 2020] 
9. https://www.sensata.com/, [Accessed: November 2020]

10. https://www.se.com/ww/en/, [Accessed: November 2020]

11. http://www.schneider-electric.bg/, [Accessed: November 2020]

12. http://www.coca-colahellenic.com/, [Accessed: November 2020]

13. http://www.nestle.bg/, [Accessed: November 2020]

14. https://www.nestle.com/, [Accessed: November 2020] 